\title{
Reflections on the Construction of University Teachers' Professional Abilities under the Background of "Internet Plus"
}

\author{
Weifeng Gao \\ Yellow River Conservancy Technical Institute \\ Kaifeng, China 475003
}

\begin{abstract}
Students' lives and life can be reshaped through the teaching activities of teachers. And in this process, the teachers need to have strong professional knowledge and skills to complete those things. Now, the Internet has influenced on people's lifestyles, ways of thinking and learning methods. And they also have undergone great changes. In addition, the development requirements of college teachers' professional abilities and the deficiency of information-based teaching make the "Internet plus" not only improve the professional abilities of teachers, but also create good learning space for students.
\end{abstract}

Keywords-"Internet Plus"; colleges and universities; teachers; career development

\section{INTRODUCTION}

The "Internet plus" plan has been put into national strategic planning since the National People's Congress and Chinese People's Political Consultative Conference (NPC and CPPCC) in 2015, which marks the arrival of China's Internet era. As a result, all of the domestic industries will be affected by its far-reaching influence, especially the higher education industry. The general secretary, Xi Jinping had a profound and positive evaluation of teachers. He pointed out that teachers played a very important role in educating people, and the teachers' professional abilities directly determined the quality of talents. Therefore, to strengthen the promotion of teachers' ability is the basis for improving the teaching quality of education. And it requires the long-term and multi-pronged efforts to complete this work. This paper discusses how to improve the teaching and learning ability of teachers in colleges and universities in the "Internet Plus" era.

\section{The Status QuO OF PROFESSIONAL AbILITY OF CHINESE UNIVERSITY TEACHERS}

At present, the scale of teachers in our country is increasing year by year, and the professional ability of teachers has been continuously improved. However, the teaching methods of modern university teachers are more rigid, and the social economy has not combined with the

This paper shows a periodic result of the project "the Construction of University Teachers' Professional Abilities under the Background of

"Internet Plus" in the "13th five-year plan" of education science in Henan province. Subject Moderator: Gao Weifeng, Project No. [2017] -JKGHYB 0345 . achievements of colleges and universities very well. For the university teachers, the space to promote the professional ability is relatively small. In addition, the university teachers absorb knowledge in different backgrounds. And the training directions of professional ability are various. And then, it forms the professional development status quo of China's university teachers.

\section{A. A University Teacher Who Lacks the Systematic Cognition of Professional Ability}

Through the investigation on the composition system of the professional ability of teachers in colleges and universities, it is found that nearly $90 \%$ of the teachers realize the professional ability system of teachers. However, the teachers know very little about the specific requirements of their own professional skills.

\section{B. The Deficiency of Relevant Mechanisms of Teachers' Professional Abilities and the Unity of Policy}

In the majority of colleges and universities, the mechanism to encourage the teachers 'professional ability is prevalent. However, this incentive mechanism still can't effectively improve the teachers' professional abilities. For example, the administrative staff of colleges and universities should have comprehensive review on the skills of competition, achievements of scientific research, arrangement of teaching tasks and management effect of students and other aspects. This approach is limited to the results of scientific research and teaching methods. And it is easy to cause the unfair evaluation of teachers who have little teaching tasks and scientific research tasks. And the enthusiasm of these teachers and teaching attitudes will be affected, which greatly affect the pride and sense of accomplishment of professional career. And the development of their professional ability has declined.

\section{College Teachers Have Less Vocational Training}

At present, the promotion of the professional ability of teachers in colleges and universities is closely related to the subjective intention of the individuals. The promotion of teachers' professional ability is mainly due to the interest of teaching and the examination mechanism of professional competence. At present, many professional institutions of 
higher education training are very few. Therefore, it should establish and improve the training on professional ability of institutions of colleges and universities.

\section{Lack of Systematic Evaluation Mechanism of Teacher Professional Ability}

The traditional way of vocational ability evaluation and teaching evaluation may be restricted to the university teachers' professional ability. The traditional evaluation system only pay attention to teachers' scientific research achievements, and ignore the teachers' thought training to student and teaching practice achievements. And it makes the university teachers' professional ability develop in oneness. And then, the teachers' professional ability can't meet the needs of social development, and it also can't meet the students' needs.

\section{ANALYSIS OF FACTORS AFFECTING THE DEVELOPMENT OF TEACHERS' PROFESSIONAL ABILITIES IN COLLEGES AND UNIVERSITIES}

\section{A. The Basis of the Development of Teachers' Professional Abilities in Colleges and Universities Is to Improve the Personal Qualities of Teachers}

The internal factors affecting the development of teachers' professional competence in colleges and universities are the individual qualities of teachers. In other words, teachers' professional knowledge, professional ethics, personal education consciousness, practical ability, research achievements and personal interest are the internal factors affecting the development of teachers' professional ability. And the professional ability of teachers' knowledge, professional ethics and personal education awareness have influenced on the development of teachers' professional ability mostly. Firstly, if teachers have higher personal qualities, they will give students all the professional knowledge they have learned and continue to learn to improve their personal qualities. Secondly, the professional ethics of teachers in colleges and universities refers to the behavioral norms formed by teachers in practical teaching, as well as moral sentiments and moral qualities. If the professional ethics of teachers in colleges and universities are relatively high, they will be strict with their own behaviors and serve the students well in actual teaching activities. Thirdly, the individual consciousness refers to teachers' awareness of their own professional competence and teaching ability in colleges and universities. Good individual consciousness means that the initiative, control and the degree of creativity of teachers' teaching activities are relatively strong. It plays an important role in improving the comprehensive level of teachers' professional ability in colleges and universities.

\section{B. The Impact of the Higher Education Policy on Improving the Teachers' Professional Ability}

The main external factors influencing the development of teachers' professional abilities in colleges and universities are the higher education policies implemented by the state. The education policy of colleges and universities can be divided into three parts. The first is the macro target policy of education. The second is programmatic resolution. And the third is the instruction on education and teaching behaviors. The higher education and teaching policy formulated by the state has a great influence on the improvement of teachers' vocational ability. The national education policy has given teachers' rights and obligations and promoted the development of teachers' professional abilities in colleges and universities.

\section{Learning Mode Is the Accelerator for the Development of Teachers' Professional Abilities}

The learning mode can be divided into two types. The first is the learning mode of the teacher's self-improvement on professional ability. The second is the learning mode of the students in the learning process. With the advent of the era of "Internet plus", the traditional learning mode already cannot satisfy the university teachers' professional development. Teachers' professional abilities not only refer to the improvement of their own qualities, but also the reform and innovation of education curriculum. Effective learning mode can help the teacher to master their own deficiencies as soon as possible. With the correct learning methods, they can make the supplement. Therefore, the innovation of teachers' learning mode and education is the need of the development of teachers' professional ability. And good learning model can provide a good help for the development of university teachers' professional ability.

\section{The CONSTRUCTION OF TEACHERs' PROFESSIONAL ABILITY IN THE ERA OF "INTERNET PLUS"}

With the development of education industry and the change of social market, the market demand of the teachers industry has changed. And it brings a new challenge to education and teaching mode of university teachers. Firstly, the demand of teachers in social market is changed from quantity to quality. Secondly, the requirement for teachers' educational qualifications is changed from high education to high quality. Thirdly, the quality requirements of university teachers are changed from the traditional single technique to the research type and the expert type. With the change of the demand of teachers in the social market, the mode of cultivating teachers is changed from single to multiple, and from closed type to open type. The mode of cultivating the teachers has changed greatly, which means that it needs to reform and innovate the education teaching mode constantly.

The Khan Academy, a famous university in the United States, has launched the innovative education and teaching model, which has received a favorable response from the teaching model of "flipped classroom". The Stanford University, Massachusetts institute of technology (MIT) and Harvard University and other colleges and universities have actively created a teaching mode "massive open online courses". The Internet education and teaching platform would be helpful to the development of education. And the teaching mode has been heavily promoted by the reform. It has further improved the education quality of teaching. With the reform of the Internet teaching mode in current age, the education and teaching in colleges and universities should 
make full use of the "Internet plus" strategy. And it also should make the innovation of the education teaching mode, which enables the student to learn knowledge on the Internet anywhere and at any time. And it broadens the students' knowledge.

\section{A. To Build a Smart-classroom to Develop an Innovative and Network-oriented Teaching Model for Pre-service Teachers}

In the era of the rapid development of Internet, it is only to make full use of the Internet technology and make the innovation of education and teaching mode and management to achieve the intelligent teaching management. Through the open Internet information platform, the excellent teaching information resources and scientific information research are made to the public to achieve the excellent resource sharing. Colleges and universities can set up the smart-classroom to develop the innovative ability of teachers, and actively develop the $3 \mathrm{D}$ printing, virtual experiments, robots and the records of the teaching activities and other methods of education and teaching. And the practice construction of education and teaching meet the needs of innovative and modern teacher training, education and teaching mode, evaluation model and teacher resources. And the, it fully make the teachers feel the modern Internet education and teaching resources, teaching mode and teaching environment, etc.

\section{B. Teachers are Actively Engaged in Learning in the Web- based Teaching Platform to Establish a Large-scale System of Training for Teachers}

According to the primary and secondary school curriculum standards and the actual needs of teaching, and it should actively promote the development of teachers' teaching courses online, and establish a perfect teaching standard and procedure of teacher curriculum resources. The professional teachers are actively engaged in learning the web-based education and teaching mode on the Internet platform. It has led to the further development of web-based teaching platform, broadening the scope of Internet teaching and building a huge network teaching team. In this way, it achieves the bidirectional development between the innovation of teaching mode and the Internet teaching platform. The teachers will conduct training and have further study through the network teaching platform. It can greatly improve teachers' professional theory knowledge, skill knowledge and so on. And it also enables the teacher to learn knowledge and theory and the advanced teaching mode in the network teaching platform. And then, it will establish the system of teachers' education training.

\section{To Enhance the Effective Synergies Between Education and Teaching Mode and Education Structures, and to Promote the Integration of Education and Teaching Mode}

With the rapid development of the Internet, it achieve the sharing of teaching curriculum and teaching information resources among the normal colleges, universities and the education training institutions. And then, it achieves the effective combination of pre-service and post-service learning contents. It gives full play to the leading role of normal universities in education and teaching. And it strengthen the collaborative innovation among the teachers' education and teaching mode, teaching content and education and training institutions. The innovation of education and teaching mode makes the teaching model develop into diversified education modes. And then, it will promote the integration of the construction of education and teaching modes.

\section{Teachers of Colleges and Universities Should Constantly Learn the Advanced Teaching and Education Mode}

Teachers in colleges and universities can stand in the education industry only according to the continuous learning of advanced knowledge. Teachers' learning ability is the foundation of scientific research ability and innovation ability. The era of the Internet has changed a lot. Therefore, teachers must explore the teaching knowledge on the "Internet Plus" in depth and understand the role of the Internet platform. And the students may learn knowledge actively with the Internet platform. Students can get the basic knowledge through the Internet platform. Therefore, if the teachers' teaching style is single or immobilized, it may be difficult to satisfy students' thirst for knowledge. Teachers should strengthen their learning, and actively learn from the advanced teaching model of the Internet, broaden the ways of education and teaching. It can create a whole new situation of education and teaching through the diversified teaching mode, such as the slide show, video teaching and so on.

Teachers can effectively improve their professional ethics and personal qualities through continuous learning. The famous soviet educator, Ushinski once said that most of the knowledge learned by students was in a variety of professional courses arranged by the school, and in fact the quality of teachers was also an important factor affecting students' learning, and the teacher's personality played an important role in students' learning the knowledge. The teacher's good personality is an invisible force to encourage the students. Even the textbooks, the moral theories and the system of rewards and punishment can't exceed the influence of this force on students. Teachers' good professional ethics and quality can actively promote students' self-learning and improve the efficiency of education and teaching. Based on this, teachers can effectively promote the quality of education and teaching by constantly reading and learning. And they also can improve their own knowledge reserve and professional ethics and personal qualities.

\section{E. The Reform and Innovation of Education and Teaching Mode in Class}

With the rise of "Internet plus education", the Internet Online Mooc, flipped classroom, micro-course online video, online classroom and other teaching forms have got unprecedented development. The education and teaching mode of traditional classroom has a severe challenge. Teachers should keep abreast with the times. And it should 
timely reform the education and teaching mode of the classroom, promote the development of new education and teaching methods, and effectively improve the quality of education and teaching in class.

With the development of the "Internet plus" era, the flipped classroom has become a new model of teaching and education in colleges and universities at present. Unlike the traditional education and teaching mode, teachers will take video teaching as the main content in class. And it allows the students to have studies and thinking independently. And then, the students will have discussion with the teachers and the classmates in the classroom, which has changed the traditional education and teaching model "the first is to teach, second is to learn". However, this new teaching mode has brought challenges to teachers' teaching, and teachers can fully mobilize students' learning enthusiasm by exploring new modes of teaching.

The traditional education and teaching mode is that the students learn knowledge from teachers in the classroom. And the students have the discussion with the teachers. Also, they cooperate with each other. Teachers can make the teaching materials according to the practical needs of teaching. And teachers can adjust the teaching materials and the process of the classroom according to the teaching quality and the students' learning situation in time. And the emerging teaching mode of flipped classroom is that the students learn the teaching video and slideshow independently, and then they have discussion on the existing problems after watching video in class. And this kind of teaching mode also has some problems. The problems are that whether teachers make video based on the personalized learning characteristics of the students, and whether teaching video can help students improve their knowledge, and whether they can motivate students' initiatives to learn. And this requires teachers to have good ability of teaching design. Based on this, the teacher shall have a thorough understanding of students learning goals and interests before making the teaching video. According to students' individual differences and learning habits, the teachers can develop a teaching video which is accord with the actual needs of students. And it can fully mobilize students' learning interest and motivation of independent learning. If teachers' teaching video is completely different from the actual demands of students, it will not motivate students' independent learning initiative, and it is more difficult to expand the discussion of classroom topics. In addition, teachers should talk to the student to carry on the positive interaction in the classroom. The teacher should be patient with the questions that students encounter in video, and discuss the problems discovered by the school students.

With the arrival of the new era of "Internet Plus", it requires the teachers to fully grasp the new education and teaching modes such as the Internet Mooc class, the flipped class, and micro-course online video. And they also need to realize the modern network teaching platform, and master the design process of the online classroom as well as the content and so on. Through continuous learning to improve the professional skills and personal accomplishment, it would promote the development of the modernized education and teaching mode in colleges and universities.

\section{CONCLUSION}

Although the education is in a large scale in China, the development of education in China is seriously restricted by the poor teaching and distribution of teachers' resources. In recent years, China has achieved some achievements in the field of education. However, there are still many new problems to be solved. In order to meet the needs of the era, the construction of the teaching staff should be focused on the expansion of the scale. And it should build a team of teachers with comprehensive knowledge skills, research and practical ability. And it should implement the strategy of "Internet plus" in the field of education. The standards of cultivating the teachers strive to have the followings: ideal faith, moral sentiment, solid academic performance, and benevolence. And it should establish a system of teacher education model with Chinese characteristics.

\section{REFERENCES}

[1] Qin Tiantang, Wang Xintao. Paradox and decomposition: a discussion on the construction of college counselor teams [J]. High education journal, 2015, (24): 191-192.

[2] Sun Li. Research on the quality of teachers of ideological and political theory in colleges and universities in ethnic minority areas [J]. Journal of Inner Mongolia university of finance and economics, 2015, (06): 62-66.

[3] Xiao fang. A brief analysis on the quality requirements of teachers in vocational colleges in China [J]. Asia-pacific education, 2016, (01) : 186.

[4] Zhao aijie. Research on the construction of faculty of independent colleges in the new period $[\mathrm{J}]$. Heilongiiang education (research and assessment on the high education), 2015, (12) : 73-75

[5] Han fubin, Dong jianmei. Research on the construction of faculty in the transformation of local undergraduate colleges and universities -based on the research of hengshui institute [J]. Higher education research (chengdu), 2015, (04) : 43-45. 